\title{
Molecular Verification of Sex-separated Straw of Simmental Cattle (Bos taurus) by Polymerase Chain Reaction (PCR)
}

\author{
Aulia Rahman ${ }^{1}$, Asmarani Kusumawati ${ }^{2},{ }^{*}$ Agung Budiyanto ${ }^{2}$, Yemi Ulviani ${ }^{1}$, Ilham \\ Fathurrahman ${ }^{1}$, Kurniawan Dwi Prihantoko ${ }^{3}$ and Lalu Unsunnidhal ${ }^{3}$ \\ ${ }^{1}$ Master of Biotechnology Programs, Graduate Schools, Universitas Gadjah Mada, Yogyakarta. \\ ${ }^{2}$ Department of Reproduction and Obstetrics, Faculty of Veterinary Medicine, Universitas Gadjah Mada, Jl. Fauna \\ No.2, Karangmalang, Sleman, Yogyakarta. \\ ${ }^{3}$ Doctor of Veterinary Science Programs, Faculty of Veterinary Medicine, Universitas Gadjah Mada, Yogyakarta. \\ *Corresponding author.Email:uma_vet@ugm.ac.id
}

\begin{abstract}
The application of sexing technology to separate $\mathrm{X}$ and $\mathrm{Y}$ spermatozoa is a strategic step to fulfill the beef demand in Indonesia. Current sexing methods like gradient density percoll, bovine serum albumin, and spectrophotometry did not have $100 \%$ accuracy to separate between X and Y spermatozoa. The molecular verification process by Polymerase Chain Reaction (PCR) assay becomes an important step to verify the sex-separated straw of Simmental cattle, so a higher percentage of sex suitability of calves expected by farmers is achieved. This research aims to develop a new primer for Y-chromosome bearing spermatozoa in the sex-separated straw of Simmental cattle by PCR assay. Primer design for PCR assay is an important step. In this research, primer was designed by bioinformatics analysis using primer3plus based on Sex determining Region Y (SRY) gene, which encodes the male sex determination in spermatozoa. Genomic DNA of spermatozoa was isolated by PureLink Genomic DNA Mini Kit (Invitrogen, USA). Primer design by bioinformatics analysis obtained primer products of 232 bp length with $50 \%$ of GC content. The amplification of SRY primer produced a single fragment of $232 \mathrm{bp}$, respectively. Thus, this primer can be used to verify the copy of the SRY gene in the sex-separated straw of Simmental cattle.
\end{abstract}

Keywords: sex-separated straw, SRY gene, primer design, PCR, Simmental cattle.

\section{INTRODUCTION}

Sexing is a technology to separate between $\mathrm{X}$ and $\mathrm{Y}$ spermatozoa, thus, the sex of prospective calves could be determined. Sexing methods did not have $100 \%$ accuracy to separate between X spermatozoa and Y spermatozoa [1]. Most farmers expected a higher percentage of sex suitability between straw and further calves. Therefore, molecular verification by Polymerase Chain Reaction (PCR) assay becomes an important step to verify the sexseparated straw of cattle.

Sex determining Region Y (SRY) gene located at Y chromosomes, is a determinant gene for males in spermatozoa [2]. SRY gene located at non recombinant site of $\mathrm{Y}$ chromosomes has single exon that encodes 204 amino acids [3]. The structure of SRY gene correlated with homeobox (HMG, known as housekeeping gene) on the central site. One of housekeeping gene in mammals is GADPH, that has a conservative region for species differentiation. Correlation between SRY-HMG can be used for DNA-based sex determining analysis [4]. National production of beef in Indonesia is only fulfill about $45 \%$ of beef demand, so breeding and reproductive technologies should be developed to improve the domestic beef production in Indonesia [12]. To increase the production of beef, artificial insemination by Y sexseparated straw is required. Male $(\mathrm{Y})$ sex-separated straw of Simmental cattle was used in this research. Simmental is a dual-purpose cattle, it can produce both milk and beef. It's because Simmental cattle produces a high level of carcass with little fat. Besides that, Simmental cattle have benign characters, calm, and easy to handle [5]. 
There are several techniques to evaluate the true chromosomal content of spermatozoa after sexing procedures, such as Fluorescence in situ Hybridization (FISH) [6];[7], quinacrine mustard staining for Ychromosomes [8], and Polymerase Chain Reaction (PCR). PCR is a simple, faster, and cost effective methods to identify the suitability of sex-separated straw with only a single reaction tube [13]. PCR assay was chosen because it is effective, accurate, rapid, and efficient because it just needs a small amount of genomic DNA. This study was carried out to develop a new primer for Y-chromosome bearing spermatozoa in the sexseparated straw sample of Simmental cattle using PCR assay.

\section{MATERIAL AND METHODS}

\subsection{Materials}

The materials used in this research are: three samples of Sex-separated spermatozoa of Simmental cattle (Ysperm), PureLink Genomic DNA Mini Kit (Invitrogen, USA), primers (Gene Universal, USA), GoTaq Green Mastermix (Promega, USA), nuclease-free water (Biobasic, USA), SeaKem LE Agarose (Thermo Fisher Scientific, USA), TAE Buffer (Invitrogen, USA), SYBr Gel Staining (Invitrogen, USA), 100bp marker (Vivantis NL 1407).

\subsection{Methods}

\subsubsection{Sample Preparations}

Three straw Samples (Y-straw) of Simmental cattle were collected from an insemination institute. Straw samples were thawed in a waterbath, temperature $37{ }^{\circ} \mathrm{C}$ for 30 seconds. The genomic DNA of spermatozoa was extracted using a commercial DNA extraction kit (PureLink Genomic DNA Mini Kit, Invitrogen, USA) according to the manufacturer's instruction manual. DNA concentration and purity were measured with DNA quantification spectrophotometer device (MN-913A MaestroNano Pro, MaestroGen, Taiwan).

\subsubsection{Primers Design}

The primer was designed for the amplification process, based on Bos taurus Sex determining Region Y (SRY) gene in the GenBank database (acession number NM-0101485.1). Primer was developed to detect Ychromosome bearing spermatozoa of Bos taurus. The forward and reverse primers were designed by primer 3 plus web. The Y-specific primers (forward: 5'-TCC AGC TGT GGT ACA GCAA-3' and reverse: 5-'AGC TGC TTG CTG ATG TCTGA-3') presenting an amplification's product size of $232 \mathrm{bp}$.

\subsubsection{Polymerase Chain Reaction (PCR) Assay}

Polymerase Chain Reaction (PCR) assay was performed using a thermal cycler device (2720 Thermal Cycler, Applied Biosystems ${ }^{\mathrm{TM}}$, USA). The PCR consisted of $10 \mu \mathrm{l}$ reaction containing $5 \mu \mathrm{l}$ master mix (GoTaq Green Mastermix, Promega, USA), $2 \mu 1$ nuclease-free water (Biobasic, USA), $2 \mu \mathrm{l}$ Y-sperm DNA of Simmental cattle, forward and reverse primers each $0.5 \mu \mathrm{l}$ (Gene Universal, USA). The amplification process started with a predenaturation step at $94{ }^{\circ} \mathrm{C}$ for $5 \mathrm{~min}$. Amplification has been done for 45 cycles. Each cycle of amplification steps of denaturation at $94{ }^{\circ} \mathrm{C}$ for $30 \mathrm{~s}$, annealing at $55{ }^{\circ} \mathrm{C}$ for $30 \mathrm{~s}$, and extension at $72{ }^{\circ} \mathrm{C}$ for 30 seconds. The cycle ends with the final extension process at $72{ }^{\circ} \mathrm{C}$ for $10 \mathrm{~min}$ and the hold time at $4{ }^{\circ} \mathrm{C}$.

\subsubsection{Electrophoresis}

PCR products were analyzed by electrophoresis on 1\% agarose gel (SeaKem LE Agarose, Thermo Fisher Scientific, USA) in 1X TAE Buffer (Invitrogen, USA) The gel was colored by SYBr Gel Staining (Invitrogen, USA) and the molecular marker that was used in this research is $100 \mathrm{bp}$ (Vivantis NL 1407). Electrophoresis process was done in $100 \mathrm{~V}$ for $25 \mathrm{~min}$. The gel was observed by GenSys Gel Documentation System.

\subsubsection{Statistics}

Data on this research were analyzed by descriptive statisctical analysis.

\section{RESULTS AND DISCUSSION}

Y sex-separated straw sample of Simmental cattle was collected from an insemination institute in Indonesia. From the data given by the insemination institute, post thawing motility (PTM) of straw is given on Table 1. According to Indonesian National Standard (SNI), a minimum percentage of PTM at $37{ }^{\circ} \mathrm{C}$ for 30 seconds of straw is $40 \%$ [9]. Greater PTM percentage, the pregnancy rate of cattle in the artificial insemination process becomes higher [10]. The quality of straw from the insemination institute is suitable for artificial insemination programs.

Table 1. Post thawing motility (PTM) of straw samples

\begin{tabular}{|c|c|}
\hline Sample code & PTM (\%) \\
\hline A & 45 \\
\hline B & 45 \\
\hline C & 50 \\
\hline
\end{tabular}

The DNA of Y sex-separated straw of Simmental cattle was extracted by PureLink Genomic DNA Mini Kit 
according to the manufacturer's instruction manual. The DNA concentration and purity were analyzed by a nanodrop device. The concentration of Y sex-separated straw of Simmental cattle for sample A is $16.48 \mathrm{ng} / \mu \mathrm{l}$, sample $B$ is $17.70 \mathrm{ng} / \mu \mathrm{l}$ and sample $C$ is $14.65 \mathrm{ng} / \mu \mathrm{l}$ (Table 2.).

Table 2. DNA isolation result

\begin{tabular}{|c|c|c|}
\hline $\begin{array}{c}\text { Sample } \\
\text { code }\end{array}$ & $\begin{array}{c}\text { DNA } \\
\text { concentration } \\
(\mathbf{n g} / \boldsymbol{\mu l})\end{array}$ & $\begin{array}{c}\text { DNA } \\
\text { purity } \\
(\mathbf{A 2 6 0 / 2 8 0})\end{array}$ \\
\hline A & 16.48 & 1.910 \\
\hline B & 17.70 & 1.938 \\
\hline C & 14.65 & 1.924 \\
\hline
\end{tabular}

For the PCR assay, the DNA template needed for each reaction is about 1 to $1000 \mathrm{ng} / \mu \mathrm{l}$ [11]. Genomic DNA of Y spermatozoa was suitable for PCR analysis. The DNA purity on absorbance $260 / 280 \mathrm{~nm}$ for sample A is 1.910 , sample B is 1.938 and sample $C$ is 1.924 . If the ratio of absorbance at 260 and 280 is about $1.8-2$, the DNA is pure. If the ratio is below 1.8 or more than 2, it may indicate the presence of protein, RNA or other contaminants [15].

Table 3. Forward and reverse primer design from primer 3 plus

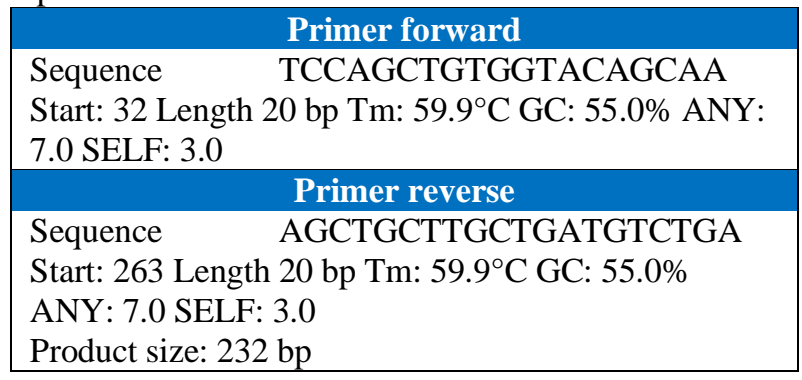

Primers for molecular verification were designed by primer 3 plus. The product size of amplification of those primers is $232 \mathrm{bp}$. The primer has $55 \%$ of GC contents, with 20 bp length (Table 3.). There are several characteristics to be noticed when designing primers such as primer length between 15 to 30 bases, GC content range about $40 \%$ to $60 \%$ to increase primer efficiency, avoid dinucleotide repeats and single base runs [11]. From the characteristics described above, the primers are qualified for PCR analysis.

Electrophoresis result showed that $\mathrm{Y}$ sex-separated straw has 1 band in 232 bp (Figure 1.). Amplicon of SRY gene has size $232 \mathrm{bp}$. From the result above, PCR methods using SRY primers could verify the Y sex-separated straw of Simmental cattle. Molecular verification by PCR is needed because current sexing methods can not separate between X and Y sperm with an accuracy of 100\% [1]. The suitability between sex-separated straw and calves was measured by conception rate and observed by rectal palpation examination at the $90^{\text {th }}$ days of preganancy [14], but it did not efficient both in time and cost. PCR was chosen because it is an amplification technique that strongly generates a specific segment of DNA with a small concentration of DNA template [11]. So, it can be a method that is more efficient in time and cost.

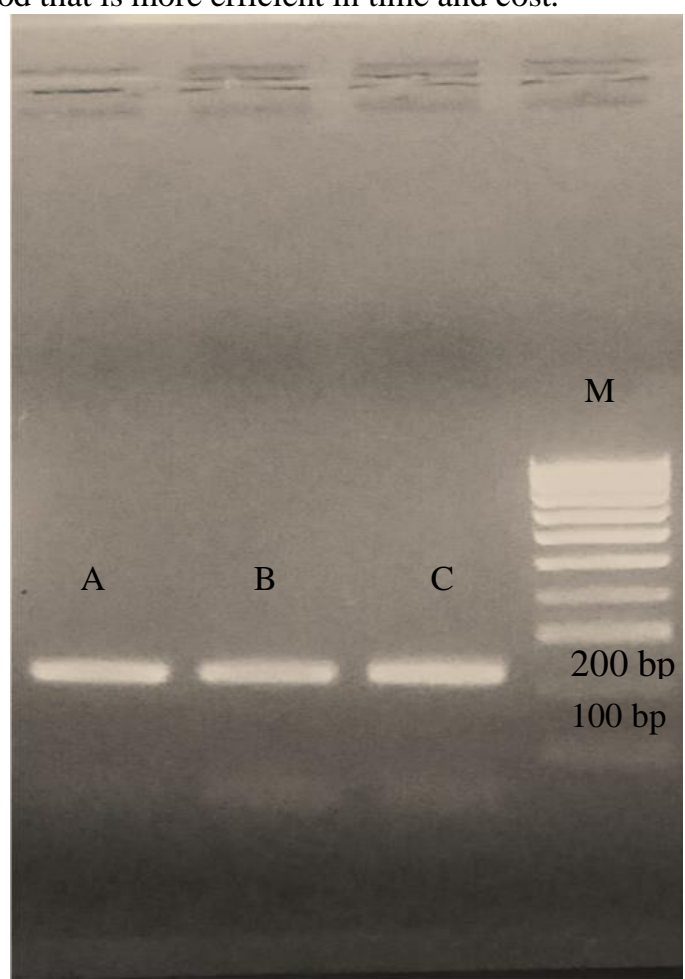

Figure 1. Electrophoresis result of molecular verification of $Y$ sex-separated straw in Simmental cattle.

SRY gene in mammals was located in the nonrecombinant region of $\mathrm{Y}$ chromosomes which is important for sex determination. The chromosomes consist of a single exon contain HMG box. Studies of HMG box and SRY gene has conserved sequences, so it can be a strong target to develop sex determination procedures based on DNA. PCR methods are able to identify the sex of cattle meat by amplifying target sequence of SRY gene without requiring genome sequencing. PCR amplification is a reliable, fast, and straightforward method for sex determination in cattle [4].The designed primer in further studies should be checked by PCR amplification to differentiate the sex determination of other mammal's spermatozoa.

\section{CONCLUSION}

The designed primers could identify the $\mathrm{Y}$ chromosomes in Y sex-separated straw of Simmental cattle using by PCR method with subsequent gel electrophoresis assay. The primer amplified the target sequence of Sex determining Region Y (SRY) gene with amplicon's product size 232 bp respectively. The verification by PCR is reliable, cheap, and be a recommendation for routine analysis after sexing. 


\section{AUTHORS' CONTRIBUTIONS}

On this paper, Aulia Rahman as the first author have a contribution for data collection, data analysis, and manuscript writing. Asmarani Kusumawati as corresponding author have a contribution for data analysis and manuscript reviews. Agung Budiyanto, Kurniawan Dwi Prihantoko, and Lalu Unsunnidhal have contribution for manuscript reviews, while Yemi Ulviani and Ilham Fathurrahman have a contribution for data collection.

\section{ACKNOWLEDGMENTS}

In accordance with the publishing of this proceedings, we would like to say thank you for Universitas Gadjah Mada that have fund this research by Dana Masyarakat, through Rekognisi Tugas Akhir (RTA) programs.

\section{REFERENCES}

[1] R. Sharma, J. Masaki, A. Agarwal, Sperm DNA fragmentation analysis using the TUNEL assay, Methods.Mol.Bio, vol. 927, Springer, Berlin, Heidelburg, 2013, pp. 121-136. DOI: https://doi.org/10.1007/978-1-62703-038-0_12.

[2] K. Parati, G. Bongioni, R. Aleandri, A. Galli, Sex ratio determination in bovine semen: a new approach by quantitative real time PCR, Theriogenology, vol. 66, Elsevier, Amsterdam, 2006, pp. 2202-2209. DOI: https://doi.org/ 10.1016/j.theriogenology.2006.07.007.

[3] Prashant, D.S. Gour, P.P. Dubey, A. Jain, S.C. Gupta, B.K. Joshi, D. Kumar, Sex determination in 6 bovid species by duplex PCR, J.App.Genet, vol. 49, Springer, Berlin, Heidelburg, 2008, pp. 379-381. DOI: https://doi.org/10.1007/BF03195637.

[4] P. Gokulakhrishnan, R.R. Kumar, B.D. Sharma, S.K. Mendiratta, O. Malav, D. Sharma, Determination of sex origin of meat and meat product on DNA basis: a review, Clin.Rev.Food.Sci.Nutr, vol. 55, Taylor\&Francis, London, 2015, pp. 1303-1314. DOI: https://doi.org/ 10.1080/10408398.2012.690095.

[5] E.T. Susilorini, Budi daya 22 ternak potensial, Penebar Swadaya, Jakarta, Indonesia, 2008.

[6] W.W.M.Z. Somarny, K. Aslinda, S. Md.Tasol, R. Mohd.Hifzan, J.M. Nasir, A.W. Mohd Hafiz, B. Ab Rashid, K. Musaddin, Verification of caprine sexedseparated spermatozoa by real time PCR, Mal.J.Animal.Sci, vol. 17, Malaysian Journal of Animal Science, Malaysia, 2014, pp. 73-83.

[7] J. Yan, H.L. Feng, Z. Chen, J. Hu, X. Gao, Y. Qin, Influence of swim-up time on the ratio of $\mathrm{X}$-and $\mathrm{Y}$ - bearing

spermatozoa,

Eur.Obstet.Gynecol.Reprod.Bio, vol. 129, Elsevier, Amsterdam, 2006, pp. 150-154. DOI: https://doi.org/10.1016/j.ejogrb.2006.02.020.

[8] S. Blottner, H. Bostedt, K. Mewes, C. Pitra, Enrichment of bovine $\mathrm{X}$ and $\mathrm{Y}$ spermatozoa by freeflow electrophoresis, J.Vet.Med.Ser, vol. 41, Elsevier, Amsterdam, 1994, pp. 466-474. DOI: https://doi.org/10.1111/j.14390442.1994.tb00113.x

[9] Badan Standarisasi Nasional, Semen beku sapi, SNI 01-4869.1-2005, Jakarta, Indonesia, 2005, pp. 1-10.

[10] T. Susilawati, Tingkat keberhasilan inseminasi buatan dengan kualitas deposisi semen yang berbeda pada sapi Peranakan Ongole, J.Ternak.Tropika, vol. 12, Malang, Indonesia, 2011, pp. 15-24.

[11] T.C. Lorenz, Polymerase chain reaction: basic protocol plus troubleshooting and optimization strategies, J.Vis.Exp, vol. 63, PubMed Central, U.S, 2011, pp. 1-15. DOI: https://doi.org/10.3791/3998.

[12] A. Agus, T.S.M. Widi, Current situation and prospect of beef cattle production in Indonesia a reviw, Asian-Australas.J.Anim.Sci, vol. 31, Animal Bioscience, Seoul, Korea, 2018, pp. 976-983. DOI: https://doi.org/10.5713/ajas.18.0233.

[13] T. Khamlor, P. Pongpiachan, S. Sangsritavong, N. Chokesajjawatee, Determination of sperm sex ratio in bovine semen using multiplex real-time polymerase chain reaction, AsianAustralas.J.Anim.Sci, vol. 27, Animal Bioscience, Seoul, Korea, 2014, pp. 1411-1416. DOI: https://doi.org/10.5713/ajas.2014.14223.

[14] M. Gunawan, E.M. Kaiin, S. Said, Aplikasi inseminasi buatan dengan sperma sexing dalam meningkatkan produktivitas sapi di peternakan rakyat, Pros.Sem.Nas.Masy.Biodiv.Indon, vol. 1, Institut Teknologi Bandung, Bandung, Indonesia, 2015, pp. 93-96.

[15] G. Lucena-Aguilar, A.M. Sanchez-Lopez, C. Barberan-Aceituno, J.A. Carrillo-Avila, J.A. LopezGuerrero, R. Aguilar-Quesada, DNA souce selection for downstream applications based on DNA quality indicators analysis, Biopreserv.Biobank, vol. 14, PubMed Central, U.S, 2016, pp. 264-270. DOI: https://doi.org/ 10.1089/bio.2015.0064. 